\title{
THE SEPARATE EFFECTS OF HYPERPARATHYROIDISM, HYPERCALCEMIA OF MALIGNANCY, RENAL FAILURE, AND ACIDOSIS ON THE STATE OF CALCIUM, PHOSPHATE, AND OTHER IONS IN PLASMA*
}

\author{
By MACKENZIE WALSER
}

(From the Department of Pharmacology and Experimental Therapeutics and Department of Medicine, Johns Hopkins School of Medicine; and the Medical Service, Johns Hopkins Hospital, Baltimore, Md.)

(Submitted for publication January 22, 1962; accepted March 8, 1962)

The physiological properties of calcium are functions of free ionic calcium. ${ }^{1}$ Total plasma calcium may fail to reflect the free calcium ion concentration, particularly in subjects with acidosis or alkalosis, or with abnormal concentrations of protein or phosphate. The determination of free ionic calcium is therefore important, not only in interpretation of plasma calcium values, but also in understanding mechanisms of hypercalcemia and hypocalcemia, and the relationship of plasma calcium to plasma phosphate.

The frog heart method of McLean and Hastings (4) for determining ionized calcium has provided much useful information but remains a difficult and somewhat unpredictable technique. Furthermore, it gives no clue as to the effective phosphate concentration and, therefore, to the mineralizing propensity of the blood. Yendt, Connor and Howard (5) showed that the tendency of plasma to calcify rachitic cartilage could be employed as a measure of mineralizing propensity. This index did not show a constant relationship to the product of ultrafiltrable calcium by ultrafiltrable phosphate in patients, especially in renal failure, in which calcification failed to occur at products that were more than adequate in non-uremic plasma. This observation implied that the ionization of calcium or phosphorus, or both, is reduced in renal failure or, alternatively, that some other constituents are inhibiting calcification.

In 1955, Raaflaub (6) introduced a chemical method for determining ionized calcium in pro-

\footnotetext{
* Supported by U.S. Public Health Service Grants A-2306 and OG-11. Some of this material has been presented previously in abstract form (1-3).

1 The role of ion-pair complexes, in which calcium is believed to be ionized but not free, is reviewed in the Discussion.
}

tein-free fluids with murexide. Results obtained with this method, referred to below, have generally confirmed the conclusions derived from experiments with the frog heart technique, both in study of normal plasma and in pathological conditions. Again, the absence of a method for determining effective phosphate concentration has limited the usefulness of these measurements in problems concerning mineralization.

We have recently reported a method for estimating both free $\mathrm{Ca}^{2+}$ and free $\mathrm{HPO}_{4}{ }^{2-}$ concentrations, using a modification of Raaflaub's technique, a new method for free $\mathrm{Mg}^{2+}(7)$, and a set of equations to derive $\mathrm{HPO}_{4}{ }^{2-}$ after allowing for complexed phosphate. The analysis of normal plasma by this procedure was the subject of a previous report (8). The purpose of the present study was to determine whether this procedure affords useful information in hypercalcemic states. in renal failure, and in subjects with both conditions.

\section{PATIENTS AND METHODS}

Patients. Most of the subjects were patients in the Johns Hopkins Hospital; a few were patients in the University of Maryland Hospital, the Baltimore City Hospital, or the Union Memorial Hospital. They have been classified in four groups and arranged in order of increasing serum urea nitrogen concentrations (Tables I and II). Chemical values given in these tables were performed in the clinical laboratories, on blood samples different from those on which the other measurements reported here were made.

1. Primary hyperparathyroidism. In 13 patients, one or more parathyroid adenomas were removed and confirmed histologically; 12 of these patients were treated surgically. The other patient (Wel) died before operation could be performed, and the suspected adenoma was found at autopsy. In Subject 14 operation has not been performed because of advanced age and debility. This subject (Ric) is nevertheless included because he presents 
the full picture of hyperparathyroidism, including polyuria, nephrolithiasis, bone changes, hypercalcemia, and hypophosphatemia. In the entire group, 7 subjects (50 per cent) had nephrolithiasis; 5 ( 36 per cent) had radiologic bone changes, 3 showing only generalized demineralization. Since these three patients were elderly, it is by no means certain that this change was due to hyperparathyroidism rather than to osteoporosis. However, alkaline phosphatase was elevated to 11 units per cent in one of these (Cro). Elevated phosphatase without demonstrated bone lesions was seen in two others. Azotemia of mild degree was seen in four. In three subjects, additional samples were obtained after parathyroidectomy.

2. Vitamin D intoxication. Two patients with hypoparathyroidism, who developed hypercalcemia and associated azotemia during therapy with vitamin $\mathrm{D}$, are included. In both, samples were obtained before hypercalcemia developed. One of these patients also had a single renal stone, apparently related to an episode of pyelonephritis.
3. Hypercalcemia of malignancy. Twelve patients with hypercalcemia secondary to neoplastic disease were studied. All but two had recognized bone lesions; X-rays and autopsy revealed no bone lesions in these two patients (Mar and Smi). All but four patients were azotemic. Seven were alkalotic (including five with azotemia), as indicated by $\mathrm{pH}$ values in excess of 7.5 in venous plasma. Three had phosphatase levels above 8 Bodansky U. Autopsies were performed in six of these patients; no parathyroid hyperplasia was found except in Subject Mar, who had one slightly enlarged and three other normal glands.

4. Renal disease. Twenty-eight patients with primary renal disease were studied. Three without azotemia are included for comparison. One showed no chemical abnormalities, one had hypermagnesemia only, and the third had hyperphosphatemia only. The other 25 patients had varying degrees of azotemia and acidosis. Only one had nephrolithiasis. Bone $\mathrm{X}$-rays were obtained in a few subjects and were negative; almost all had chest

TABLE I

Clinical data, hypercalcemic subjects

\begin{tabular}{|c|c|c|c|c|c|c|c|c|}
\hline Name & Age & Sex & Diagnoses & $\begin{array}{l}\text { Bone } \\
\text { lesions }\end{array}$ & $\begin{array}{l}\text { Renal } \\
\text { stones }\end{array}$ & SUN* & $\mathrm{CO}_{2}$ & $\begin{array}{l}\text { Alk. } \\
\text { p'tase }\end{array}$ \\
\hline & & & & & & $m g \%$ & $\underset{L}{\text { mmoles / }}$ & $U \% \dagger$ \\
\hline \multicolumn{9}{|c|}{ I. Primary hyperparathyroidism } \\
\hline Ick & 74 & $\mathrm{~F}$ & Parath. adenoma $\ddagger$ & No & No & 8 & 29 & 8.2 \\
\hline Cha & 35 & $\mathrm{~F}$ & Parath. adenoma & No & No & 9 & 24 & 6.8 \\
\hline Ric & 72 & $\mathbf{M}$ & Hyperparath. $\S$ & Yes & Yes & 10 & 29 & 5.4 \\
\hline Bar & 35 & F & Parath. adenomaf & No & Yes & 10 & & 4.7 \\
\hline Bak & 53 & $\mathrm{~F}$ & Parath. adenoma & No & Yes & 10 & 23 & 9.0 \\
\hline Cro & 61 & $\mathrm{~F}$ & Parath. adenoma & Yes $\mathbb{1}$ & No & 11 & 26 & 11.0 \\
\hline Stu & 54 & $\mathbf{M}$ & Parath. adenomaf & No & Yes & 11 & & \\
\hline $\mathrm{Aba}$ & 64 & $\mathbf{M}$ & Parath. adenoma & No & Yes & 13 & 24 & 6.0 \\
\hline Wil & 55 & $F$ & Parath. adenomaf & No & Yes & 17 & & 7.5 \\
\hline Rit & 25 & M & Parath. adenoma & Yes & Yes & 17 & 18 & 60.0 \\
\hline Wel & 72 & M & Parath. adenomaf & No & No & 21 & 25 & 6.8 \\
\hline Joh & 73 & $\mathrm{~F}$ & Parath. adenomaf & Yes & No & 30 & 25 & 5.3 \\
\hline Sla & 46 & $\mathbf{M}$ & Parath, adenomaf & Yes & No & 31 & 21 & 11.1 \\
\hline Bot & 49 & $\mathrm{~F}$ & Parath. adenomat & No & No & 33 & 22 & 10.6 \\
\hline \multicolumn{9}{|c|}{ II. Vitamin D intoxication } \\
\hline Wal & 52 & $\mathrm{~F}$ & Hypoparath.\$, treated with vit. D & No & Yes & 31 & 27 & 2.5 \\
\hline Har & 55 & $\mathrm{~F}$ & Hypoparath.\$, treated with vit. D & No & No & 33 & 30 & 2.1 \\
\hline \multicolumn{9}{|c|}{ III. Hypercalcemia of malignancy\|l } \\
\hline Bur & 85 & $\mathbf{M}$ & Carc. of lung, metast. & Yes & No & 11 & 30 & 2.2 \\
\hline Mar & 79 & $\mathbf{M}$ & Anapl. neoplasm, ?hepatoma & No & No & 12 & 26 & 4.5 \\
\hline Gra & 32 & $\mathbf{F}$ & Lymphoblastic leukemia & Yes & No & 12 & 28 & 20.8 \\
\hline Gol & 59 & $\mathrm{~F}$ & Multiple myeloma & Yes & No & 15 & 22 & 8.6 \\
\hline Col & 53 & $\mathrm{~F}$ & Carc. of breast, metast. & Yes & No & 22 & 29 & 8.7 \\
\hline Oco & 34 & $\mathrm{~F}$ & Carc. of bladder, metast. & Yes & Yes & 25 & 30 & 3.2 \\
\hline Wil & 69 & $\mathrm{~F}$ & Multiple myeloma & Yes & No & 29 & 35 & 5.0 \\
\hline Smi & 57 & $\mathbf{M}$ & Carc. of lung, metast. & No & No & 35 & 26 & 3.9 \\
\hline Bel & 60 & $\mathbf{M}$ & Carc. of lung, metast. & Yes & No & 44 & 29 & 2.9 \\
\hline Bul & 60 & $\mathbf{M}$ & Multiple myeloma & Yes & No & 53 & 24 & 2.1 \\
\hline Rub & 39 & $\mathbf{M}$ & Multiple myeloma & Yes & No & 68 & 19 & 3.0 \\
\hline Maa & 51 & $F$ & Anapl. neoplasm, ?hepatoma & Yes & No & 93 & 22 & 7.0 \\
\hline
\end{tabular}

* Serum urea nitrogen.

† Bodansky units.

$\ddagger$ Pathological diagnosis.

$\$$ Clinical diagnosis.

II Pathological diagnoses (except Mar).

T Osteoporosis only. 
TABLE II

Clinical data, subjects with renal disease

\begin{tabular}{|c|c|c|c|c|c|c|c|c|}
\hline Name & Age & Sex & Diagnoses & $\begin{array}{l}\text { Parathyroid } \\
\text { hyperplasia }\end{array}$ & $\begin{array}{l}\text { Renal } \\
\text { stones }\end{array}$ & SUN & $\mathrm{CO}_{2}$ & $\begin{array}{l}\text { Alk. } \\
\text { p'tase }\end{array}$ \\
\hline & & & & & & $m g \%$ & $\underset{L}{\text { mmoles / }}$ & $U \% *$ \\
\hline Joh & 29 & F & Chronic pyelonephritis $\dagger$ & $?$ & No & 11 & & \\
\hline Fis & 45 & $\mathbf{M}$ & Nephrosclerosis $\dagger$ & $?$ & No & 16 & 28 & 5.4 \\
\hline New & 39 & $\mathbf{M}$ & Acute glomerulonephritis $\ddagger$ & $?$ & No & 18 & 27 & \\
\hline Sta & 15 & $\mathbf{M}$ & Chronic glomerulonephritis & $?$ & No & 23 & 29 & 6.8 \\
\hline Jon & 40 & $\mathbf{F}$ & Chronic pyeloneph., nephroscler. $\ddagger$ & No & No & 33 & 28 & \\
\hline $\mathrm{Fis}$ & 42 & $\mathrm{~F}$ & Nephrosclerosis, $\neq$ diabetes $\dagger$ & No & No & 58 & 20 & 5.6 \\
\hline Edw & 77 & $\mathrm{~F}$ & Nephrosclerosis $†$ & $?$ & No & 76 & 13 & 4.8 \\
\hline Hew & 40 & $\mathbf{M}$ & Nephrosclerosis & No & No & 83 & 20 & 7.8 \\
\hline Tho & 49 & $\mathbf{M}$ & Nephrosclerosis $†$ & $?$ & Yes & 89 & 33 & 9.2 \\
\hline Gre & 67 & $\mathbf{M}$ & Nephrosclerosis $\ddagger$ & No & No & 90 & 17 & \\
\hline Dis & 46 & $\mathbf{F}$ & Subacute glomerulonephritis $\dagger$ & $?$ & No & 104 & 11 & \\
\hline Har & 59 & $\mathbf{M}$ & Chronic pyeloneph., nephroscler.ł & No & No & 113 & 11 & 5.8 \\
\hline Tyl & 68 & $\mathbf{F}$ & Chronic pyelonephritis $\uparrow$ & $?$ & No & 121 & 13 & \\
\hline Bro & 56 & $\mathbf{F}$ & Nephrosclerosis $\dagger$ & ? & No & 122 & 22 & \\
\hline War & 31 & $\mathbf{F}$ & Nephrosclerosis $\dagger$ & ? & No & 124 & 20 & \\
\hline Aut & 35 & $\mathrm{~F}$ & Chronic pyeloneph., nephroscler. $\dagger$ & ? & No & 129 & 17 & 6.7 \\
\hline Wil & 59 & $\mathbf{F}$ & Nephrosclerosis, thymomat & No & No & 152 & & \\
\hline Sta & 45 & $\mathbf{M}$ & Chronic pyeloneph., hepatitis $\ddagger$ & ? & No & 158 & 17 & 11.9 \\
\hline $\mathrm{Jac}$ & 48 & $\mathrm{~F}$ & Nephrosclerosisf & No & No & 160 & 12 & 5.1 \\
\hline Wol & 45 & $\mathrm{~F}$ & Chronic glomeruloneph. $\ddagger$ & No & No & 168 & 14 & 4.2 \\
\hline $\mathrm{Hic}$ & 49 & $\mathbf{M}$ & Nephrosclerosis $\ddagger$ & Yes & No & 172 & 18 & \\
\hline Seg & 55 & $\mathbf{M}$ & Nephrosclerosis & $?$ & No & 194 & & \\
\hline Goo & 48 & $\mathbf{M}$ & Nephrosclerosis $f$ & No & No & 208 & 13 & \\
\hline Fri & 40 & $\mathrm{~F}$ & Nephrosclerosis $f$ & No & No & 210 & 18 & \\
\hline She & 58 & $\mathbf{M}$ & Chronic pyelonephritis & ? & No & 214 & 8 & \\
\hline Flo & 49 & $\mathbf{M}$ & Nephrosclerosis $f$ & Yes & No & 218 & 11 & 1.9 \\
\hline Lip & 56 & $\mathbf{M}$ & Chronic pyelonephritis & No & No & 252 & 13 & \\
\hline $\mathrm{Bie}$ & 53 & $\mathbf{M}$ & Nephrosclerosist & Yes & No & 300 & 17 & 3.4 \\
\hline
\end{tabular}

* Bodansky units.

† Clinical diagnosis.

\$ Pathological diagnosis.

films or kidney films, or both, which showed no bone lesions. Alkaline phosphatase levels were obtained in half of the subjects and were above 8 Bodansky $U$ in only two. The parathyroid glands were examined at autopsy in 13 patients and at operation in one (Bie). Hyperplasia was found in the operated subject and in two others. The diagnosis "nephrosclerosis" in the table refers to arteriosclerosis or arteriolosclerotic nephropathy associated with hypertension, or both. One patient (Wil) was found at autopsy to have a malignant thymoma. This had extended only locally, and no bone lesions were detected. Subject Bie underwent hemodialysis and parathyroidectomy and is discussed further in Results.

Methods. In each subject, 35 to $50 \mathrm{ml}$ of venous blood was obtained anaerobically with minimal stasis in a heparinized syringe. In almost every instance the subjects were either fasting or in the postabsorptive state. Annino and Relman (9) have shown that an ordinary breakfast has no effect on any of the constituents measured in this study except phosphate, which falls about 30 per cent 45 minutes after eating but has returned to the fasting value within 2 hours. Plasma was separated promptly, and $\mathrm{pH}$ was determined at room temperature. $\mathrm{pH}$ values were corrected for temperature by adding $0.01 \mathrm{U}$ per ${ }^{\circ} \mathrm{C}$. Plasma was stored under oil in the frozen state until analyzed. In hypercalcemic plasma, 100 per cent $\mathrm{CO}_{2}$ was bubbled through the samples for a few minutes before storage. Prior to ultrafiltration, the $\mathrm{pH}$ was permitted to rise to the original value by exposure to air. At the start of ultrafiltration the $\mathrm{pH}$ was therefore identical with the $\mathrm{pH}$ of venous plasma. The ultrafiltration chambers were filled with 5 per cent $\mathrm{CO}_{2}$. In samples with low $\mathrm{pCO}_{2}$ values this might tend to lower $\mathrm{pH}$ during ultrafiltration. However, only moderately reduced $\mathrm{pCO}_{2}$ values were encountered (see below). Ultrafiltration was carried out at $35^{\circ}$ to $39^{\circ} \mathrm{C} .{ }^{2}$

2 One of the reviewers of this paper raised the question as to whether complexed calcium (particularly $\mathrm{CaHCO}_{3}{ }^{+}$) might be altered by adding Tris buffer to ultrafiltrates. There are two conceivable ways in which this might occur. 1) Tris might complex calcium or some of the calcium ligands in solution. We have shown (7) that measured $\left[\mathrm{Ca}^{2+}\right]$ in standard solutions is the same in Tris buffer and diethylbarbiturate buffer, after allowance for complexing by the latter. We have also shown that Tris does not complex citrate (J. phys. Chem. 1961, 65, 159). It has apparently not been shown that Tris forms any complexes other than with transition metals. 2) Bicarbonate or other anions might complex less calcium than in native plasma, owing to lowered concentrations. However, the bicarbonate concentration is not reduced significantly more than that of other anions, the percentage decrease being 20 for all. Since allowance for this dilution factor is made in calculating the results, the underestimation of complexed calcium cannot exceed 20 
TABLE III

Observed data, hypercalcemic subjects

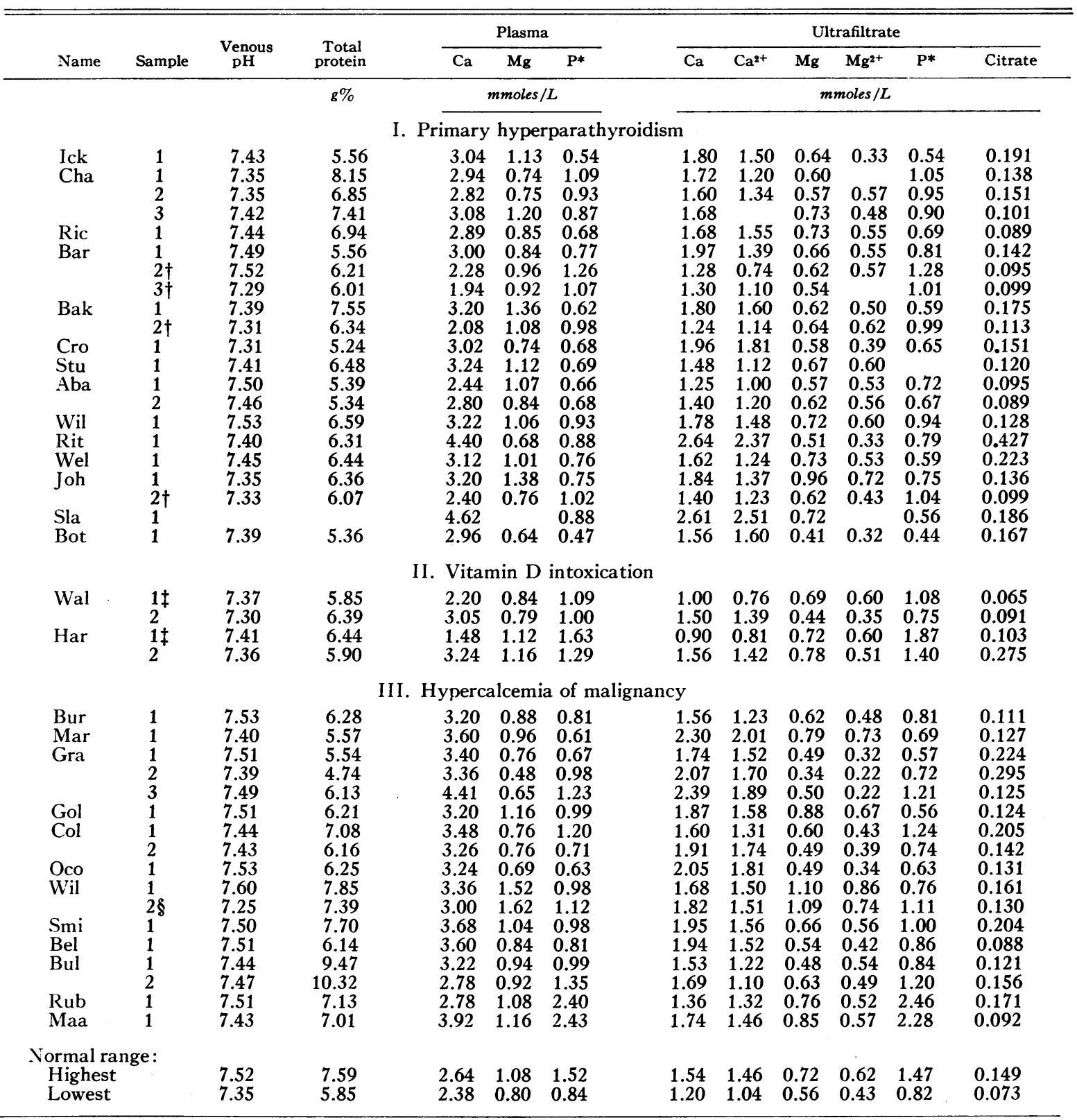

* Inorganic phosphate.

$\uparrow$ After parathyroidectomy.

+ Before vitamin D intoxication.

$\S$ After $\mathrm{NH}_{4} \mathrm{Cl}$.

The analytical methods were as previously described $(7,8)$. In subjects with hyponatremia, the standard per cent, and for anions that are predominantly free in plasma, such as bicarbonate, the extent of underestimation would approach zero. The question of whether bicarbonate does in fact complex any calcium is reviewed in reference 8 . solutions for the $\mathrm{Ca}^{2+}$ and $\mathrm{Mg}^{2+}$ methods were diluted to the same ionic strength as that of the patient's plasma. Ionic strength was roughly estimated as being equal to the sodium concentration. The dependence of these methods on ionic strength is slight in the physiological range (7). In a few of the earliest analyses, which were in subjects with renal failure, heavy metals were not re- 
TABLE IV

Observed data, subjects with renal disease

\begin{tabular}{|c|c|c|c|c|c|c|c|c|c|c|c|c|}
\hline \multirow[b]{2}{*}{ Name } & \multirow[b]{2}{*}{ Sample } & \multirow{2}{*}{$\begin{array}{c}\text { Venous } \\
\mathrm{pH}\end{array}$} & \multirow{2}{*}{$\begin{array}{c}\text { Total } \\
\text { protein }\end{array}$} & \multicolumn{3}{|c|}{ Plasma } & \multicolumn{6}{|c|}{ Ultrafiltrate } \\
\hline & & & & $\mathrm{Ca}$ & $\mathbf{M g}$ & P* & $\mathrm{Ca}$ & $\mathrm{Ca}^{2+}$ & $\mathbf{M g}$ & $\mathbf{M g}^{2+}$ & $\mathbf{P}^{*}$ & Citrate \\
\hline & & & $g \%$ & \multicolumn{3}{|c|}{ mmoles $/ L$} & \multicolumn{6}{|c|}{ mmoles $/ L$} \\
\hline Joh & 1 & 7.46 & 6.61 & 2.52 & 0.70 & 1.07 & 1.42 & 1.17 & 0.53 & 0.54 & 0.99 & 0.116 \\
\hline Fis & 1 & 7.53 & 6.65 & 2.30 & 1.20 & 1.02 & 1.30 & 1.18 & & 0.68 & 0.98 & 0.095 \\
\hline New & 1 & 7.46 & 5.54 & 2.32 & 1.07 & 1.61 & 1.38 & 1.26 & 0.64 & 0.61 & 1.47 & 0.112 \\
\hline Sta & 1 & 7.45 & 5.93 & 2.35 & 0.92 & 1.67 & 1.26 & 1.27 & 0.57 & 0.57 & 1.60 & 0.145 \\
\hline Jon & 1 & 7.50 & 7.22 & 2.31 & 1.23 & 1.70 & .1 .29 & 1.21 & & 0.75 & 1.59 & 0.147 \\
\hline Fis & 1 & 7.36 & 5.70 & 2.17 & 1.16 & 2.05 & 1.22 & 1.10 & 0.68 & 0.56 & 1.92 & 0.158 \\
\hline Edw & 1 & 7.34 & 5.96 & 2.09 & 1.60 & 1.75 & 1.19 & 1.08 & 1.11 & 0.78 & 1.71 & 0.190 \\
\hline & 2 & 7.36 & 5.72 & 1.73 & & 3.14 & 1.03 & 0.63 & 0.83 & 0.50 & 3.05 & 0.102 \\
\hline Hew & 1 & 7.41 & 8.08 & 2.26 & 0.98 & 1.49 & 1.33 & 1.22 & 0.53 & 0.41 & 1.26 & 0.076 \\
\hline Tho & 1 & 7.60 & 7.39 & 2.56 & 1.39 & 1.41 & 1.38 & 1.09 & 1.04 & 0.65 & 1.41 & 0.183 \\
\hline Gre & 1 & 7.28 & 6.47 & 2.32 & 0.81 & 1.12 & 1.59 & 1.23 & 0.47 & 0.34 & 1.03 & 0.123 \\
\hline Dis & 1 & 7.06 & 5.53 & 2.14 & 0.98 & 3.44 & 1.43 & 1.18 & 0.91 & 0.76 & 3.08 & 0.127 \\
\hline Har & 1 & 7.18 & 6.24 & 1.87 & 0.65 & 1.97 & 1.30 & 1.03 & 0.30 & 0.24 & 1.80 & 0.094 \\
\hline Tyl & 1 & 7.16 & 5.62 & 1.60 & 0.80 & 2.54 & 0.92 & 0.71 & 0.64 & 0.27 & 2.67 & 0.108 \\
\hline Bro & 1 & 7.36 & 6.59 & 1.90 & 1.11 & 1.80 & 1.02 & 0.84 & 0.93 & 0.81 & 1.58 & 0.183 \\
\hline War & 1 & 7.38 & 6.93 & 2.30 & 1.08 & 3.02 & 1.38 & 0.83 & 0.59 & 0.34 & 3.05 & 0.134 \\
\hline Aut & 1 & 7.36 & 5.11 & 2.16 & 1.62 & 2.83 & 1.46 & 1.04 & 1.40 & 1.20 & 2.89 & 0.107 \\
\hline \multirow[t]{2}{*}{ Wil } & 1 & 7.29 & 6.99 & 2.42 & 1.83 & 1.71 & 1.60 & 1.24 & 1.04 & & 1.57 & 0.173 \\
\hline & 2 & 7.28 & 6.22 & 2.11 & 1.37 & 1.41 & 1.14 & 0.96 & 1.31 & 0.96 & 1.26 & 0.100 \\
\hline Sta & 1 & 7.46 & 6.81 & 2.34 & 0.89 & 1.80 & 1.49 & 0.96 & 0.62 & & 1.64 & 0.197 \\
\hline \multirow{2}{*}{ Jac } & 1 & 7.26 & 5.78 & 1.91 & 0.90 & 3.18 & 0.94 & 1.08 & 0.73 & 0.40 & 3.03 & 0.080 \\
\hline & 2 & 7.31 & 5.68 & 2.24 & 1.25 & 1.81 & 1.51 & 1.44 & 0.77 & 0.78 & 1.79 & 0.091 \\
\hline Wol & 1 & 7.42 & & & & & 1.03 & 0.80 & 2.18 & 1.00 & 2.20 & 0.096 \\
\hline Hic & 1 & 7.41 & 7.36 & 2.14 & 1.53 & 5.32 & 1.10 & 0.99 & 1.14 & 0.58 & 5.14 & 0.076 \\
\hline Seg & 1 & 7.28 & 6.44 & 1.63 & 1.20 & 5.07 & 1.37 & 0.64 & 0.76 & 0.66 & 5.23 & 0.134 \\
\hline Goo & 1 & 7.14 & 5.70 & 2.27 & & 2.79 & 1.38 & 1.22 & 1.09 & 0.87 & 2.57 & 0.106 \\
\hline \multirow[t]{2}{*}{ Fri } & 1 & 7.24 & 5.56 & 1.56 & 1.58 & 7.06 & 0.83 & 0.31 & 1.17 & & 6.96 & 0.096 \\
\hline & 2 & 7.40 & & & & & 0.88 & 0.42 & 1.10 & 0.52 & 7.89 & 0.090 \\
\hline She & 1 & 7.16 & 6.20 & 1.62 & & 3.48 & 1.07 & 0.74 & 0.48 & 0.18 & 3.36 & 0.071 \\
\hline Flo & 1 & 7.27 & 4.93 & 2.32 & 0.84 & 3.33 & 1.66 & 1.32 & 0.68 & 0.51 & 3.49 & 0.042 \\
\hline Lip & 1 & 7.27 & 6.90 & 1.82 & 1.18 & 4.03 & 1.05 & 0.58 & 0.97 & 0.66 & 4.49 & 0.071 \\
\hline \multirow[t]{6}{*}{$\mathrm{Bie}$} & 1 & 7.30 & 4.76 & 2.52 & 1.00 & 4.65 & 1.32 & 0.78 & 0.88 & 0.53 & 4.95 & 0.063 \\
\hline & 2 & 7.35 & 5.19 & 2.48 & 1.00 & 2.19 & 1.28 & 1.02 & 0.66 & 0.45 & 2.16 & 0.067 \\
\hline & $3 \dagger$ & 7.35 & 5.33 & 1.76 & 0.92 & 2.88 & 0.84 & 0.64 & 0.72 & 0.51 & 3.23 & 0.084 \\
\hline & $4 \dagger$ & 7.13 & 6.16 & 1.44 & 0.96 & 3.99 & 0.92 & 0.63 & 0.67 & 0.53 & 4.35 & 0.116 \\
\hline & $5 \dagger$ & 7.09 & 6.01 & 1.48 & 1.04 & 4.31 & 0.77 & 0.50 & 0.72 & 0.50 & 4.77 & 0.138 \\
\hline & $6 \dagger$ & 7.30 & 5.05 & 1.36 & 1.04 & & 0.74 & 0.50 & 0.82 & 0.54 & 3.23 & 0.073 \\
\hline \multicolumn{13}{|c|}{ Normal range: } \\
\hline \multirow{2}{*}{\multicolumn{2}{|c|}{$\begin{array}{l}\text { Highest } \\
\text { Lowest }\end{array}$}} & 7.52 & 7.59 & 2.64 & 1.08 & 1.52 & 1.54 & 1.46 & 0.72 & 0.62 & 1.47 & 0.149 \\
\hline & & 7.35 & 5.85 & 2.38 & 0.80 & 0.84 & 1.20 & 1.04 & 0.56 & 0.43 & 0.82 & 0.073 \\
\hline
\end{tabular}

* Inorganic phosphate.

$\dagger$ After parathyroidectomy.

moved before determination of $\mathrm{Ca}^{2+}$ and $\mathrm{Mg}^{2+}$. This causes a greater error in the $\mathrm{Mg}^{2+}$ than in the $\mathrm{Ca}^{2+}$ method (7) and may account for the fact that free ionic magnesium appeared to exceed ultrafiltrable magnesium in a few samples (Sta and Jac).

\section{RESULTS}

Observed data in the patients are given in Tables III and IV. The range of values in 24 normal subjects, including 20 previously presented (8), is also shown. Statistical comparison was not made because the data were not normally distributed. The data have been analyzed in terms of the separate effects of 1) azotemia, 2) acidosis, 3) hyperparathyroidism, and 4) hypercalcemia of other types, upon several parameters : 1) the percentage ionization of plasma calcium; 2) the ion product $\left.\left[\mathrm{Ca}^{2+}\right] \times\left[\mathrm{HPO}_{4}{ }^{2-}\right] ; 3\right)$ the ability of the plasma proteins to bind calcium, measured as $K_{\text {CaProt }}$; and 4 ) the fraction of plasma calcium present as diffusible complexes.

\section{Percentage ionization of plasma calcium}

1. Role of acidosis and of renal failure. It is often stated that the hypocalcemia of uremia does not usually produce tetany because of the associated acidosis. The protective effect of acidosis 
is attributed to one or both of the following mechanisms : first, an alteration in the percentage ionization of calcium due to diminished protein binding; and second, a specific effect of the hydrogen ion itself on neuromuscular irritability. As indicated in Figure 1, the percentage ionization of calcium was no higher in uremic subjects with severe acidosis (venous $\mathrm{pH}<7.30$ ) than in those with mild acidosis, normal $\mathrm{pH}$, or mild alkalosis. In fact, it was frequently subnormal (in one-third of the acidotic samples). As indicated below, this was due to increased amounts of diffusible calcium complexes rather than to increased protein-bound calcium. Only one subject (Jac) showed a high percentage ionization of plasma calcium; total calcium was close to normal in this sample, so that tetany would not have been anticipated. Despite subnormal calcium ion concentrations in more than half of the azotemic subjects, tetany was not seen; positive Chvostek signs, however, were elicited in several patients. Tremulousness, convulsions, and coma were not predictably related to calcium or magnesium ion concentrations. Carpopedal spasm was not seen, even at calcium ion concentrations one-fourth of normal (Fri) or after parathyroidectomy (Bie).

In the nonacidotic uremics, the percentage ionization of calcium was usually normal. Furthermore, in the three groups of hypercalcemic subjects, the azotemic samples exhibited neither higher nor lower percentage ionization values. Mild to moderate renal failure thus has no effect

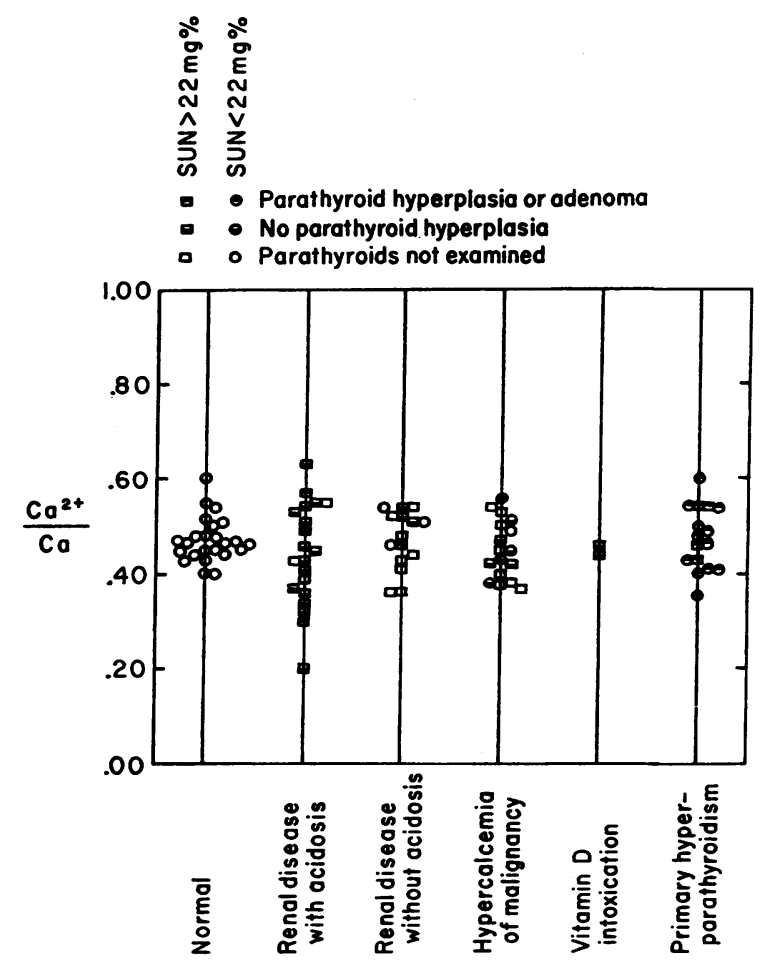

Fig. 1. The ratio of Free IONIC Calcium to total PLASMA CALCIUM IN SIX GROUPS OF PATIENTS.

on the ionization of plasma calcium. A decrease in ionization may occur in severe uremia.

2. Role of hypercalcemia. The percentage of plasma calcium bound to protein is not altered by moderate elevations of plasma calcium (10). One would not anticipate, therefore, that the percent-

TABLE V

Effect of parathyroidectomy on four indices of the state of plasma calcium

\begin{tabular}{|c|c|c|c|c|c|c|}
\hline Subject & Sample & {$[\mathrm{Ca}]$} & $\begin{array}{c}\text { Ratio } \\
{\left[\mathrm{Ca}^{2+}\right] /[\mathrm{Ca}]}\end{array}$ & $K_{\text {caProt }}$ & {$\left[\mathrm{Ca}^{2+}\right]\left[\mathrm{HPO}_{4}^{2-}\right]$} & Complexed $\mathrm{Ca}$ \\
\hline \multicolumn{4}{|c|}{ mmoles $/ L$} & $M$ & $M \times 10^{-6}$ & $\%$ of total \\
\hline \multicolumn{7}{|c|}{ Primary hyperparathyroidism } \\
\hline Bar & $\begin{array}{l}\text { Preop. } \\
\text { Postop. } \\
\text { Postop. }\end{array}$ & $\begin{array}{l}3.00 \\
2.28 \\
1.94\end{array}$ & $\begin{array}{l}0.46 \\
0.32 \\
0.53\end{array}$ & $\begin{array}{l}0.0110 \\
0.0084 \\
0.0109\end{array}$ & $\begin{array}{l}0.59 \\
0.50 \\
0.57\end{array}$ & $\begin{array}{l}19 \\
24 \\
10\end{array}$ \\
\hline Bak & $\begin{array}{l}\text { Preop. } \\
\text { Postop. }\end{array}$ & $\begin{array}{l}3.20 \\
2.08\end{array}$ & $\begin{array}{l}0.50 \\
0.55\end{array}$ & $\begin{array}{l}0.0100 \\
0.0102\end{array}$ & $\begin{array}{l}0.49 \\
0.58\end{array}$ & $\begin{array}{l}6 \\
5\end{array}$ \\
\hline Joh & $\begin{array}{l}\text { Preop. } \\
\text { Postop. }\end{array}$ & $\begin{array}{l}3.20 \\
2.40\end{array}$ & $\begin{array}{l}0.43 \\
0.51\end{array}$ & $\begin{array}{l}0.0087 \\
0.0090\end{array}$ & $\begin{array}{l}0.52 \\
0.65\end{array}$ & $\begin{array}{r}15 \\
7\end{array}$ \\
\hline \multicolumn{7}{|c|}{ Secondary hyperparathyroidism } \\
\hline Bie & $\begin{array}{l}\text { Preop. } \\
\text { Postop. }\end{array}$ & $\begin{array}{l}2.48 \\
1.76\end{array}$ & $\begin{array}{l}0.41 \\
0.36\end{array}$ & $\begin{array}{l}0.0055 \\
0.0051\end{array}$ & $\begin{array}{l}1.13 \\
1.06\end{array}$ & $\begin{array}{l}10 \\
11\end{array}$ \\
\hline
\end{tabular}




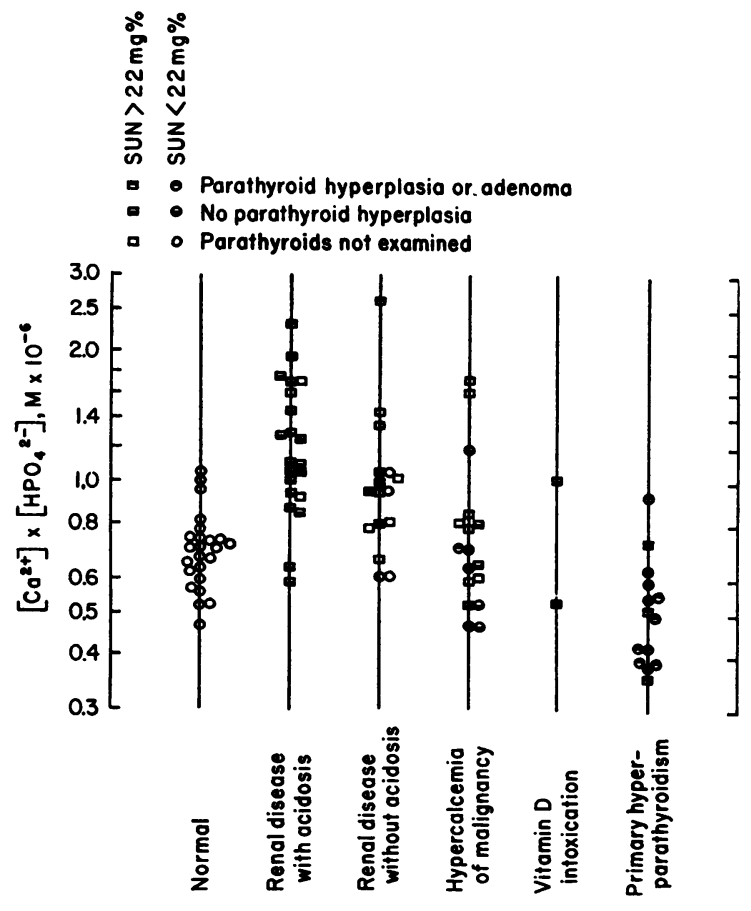

Fig. 2. The PRODUCT OF FREE CALCIUM ION CONCENTRATION BY FREE DIBASIC PHOSPHATE ION CONCENTRATION IN THE SAME sUBJECTS. The scale is logarithmic, in order to emphasize the low values seen in some subjects.

age ionization of plasma calcium would change unless some other specific effects occurred. As Figure 1 shows, no alteration in percentage ionization was noted in these 34 hypercalcemic samples.

3. Role of hyperparathyroidism. In neither primary nor secondary hyperparathyroidism was there a significant change in percentage ionization. Parathyroidectomy in four subjects failed to alter this value (Table $V$ ). The significance of these findings in comparison with other studies is considered in the Discussion.

\section{The ion product $\left[\mathrm{Ca}^{2+}\right]\left[\mathrm{HPO}_{4}{ }^{2-}\right]$}

In Figure 2 are shown the calculated values for this product in the various groups of subjects, designated in the same manner as in Figure 1. It should be emphasized that the value $\left[\mathrm{HPO}_{4}{ }^{2-}\right.$ ] is calculated, rather than measured directly (8). A logarithmic scale has been used in order to emphasize the low values seen in some subjects.

1. Role of acidosis. Since the relative proportion of the ions $\mathrm{HPO}_{4}{ }^{2-}$ and $\mathrm{H}_{2} \mathrm{PO}_{4}{ }^{-}$is dictated by $\mathrm{pH}$, the percentage of total plasma phosphate present as $\mathrm{HPO}_{4}{ }^{2-}$ was smaller in the severely acidotic subjects. Nevertheless, the product $\left[\mathrm{Ca}^{2+}\right]\left[\mathrm{HPO}_{4}{ }^{2-}\right]$ was somewhat larger, on the average. These acidotic subjects usually had more severe uremia (see Table II). Since renal failure tends to raise this product, as indicated below, the higher products found probably reflect an effect of renal failure rather than of acidosis.

2. Role of renal failure. In many of the azotemic subjects (including those without parathyroid hyperplasia) this product was considerably increased, often many-fold, as a result of a rise in $\left[\mathrm{HPO}_{4}{ }^{2-}\right]$. There was some correlation between the product and the degree of azotemia, as shown in Figure 3. Similarly, higher products were seen in those hypercalcemic subjects who were also azotemic.

3. Role of hypercalcemia. In the hypercalcemia of malignancy, the product $\left[\mathrm{Ca}^{2+}\right]\left[\mathrm{HPO}_{4}{ }^{2-}\right]$ was not elevated in the absence of azotemia except in one subject. No discernible effect of hypercalcemia per se on this product is seen in these samples, despite elevated ionic calcium concentrations in most of them. This is because $\mathrm{HPO}_{4}{ }^{2-}$ concentrations tended to fall in reciprocal fashion until renal failure supervened. In the two subjects with hypoparathyroidism, the development of vitamin $\mathrm{D}$ intoxication was associated with only a slight rise in this product despite the appearance of azotemia; in other words, $\left[\mathrm{HPO}_{4}{ }^{2-}\right]$ fell (Table VI).

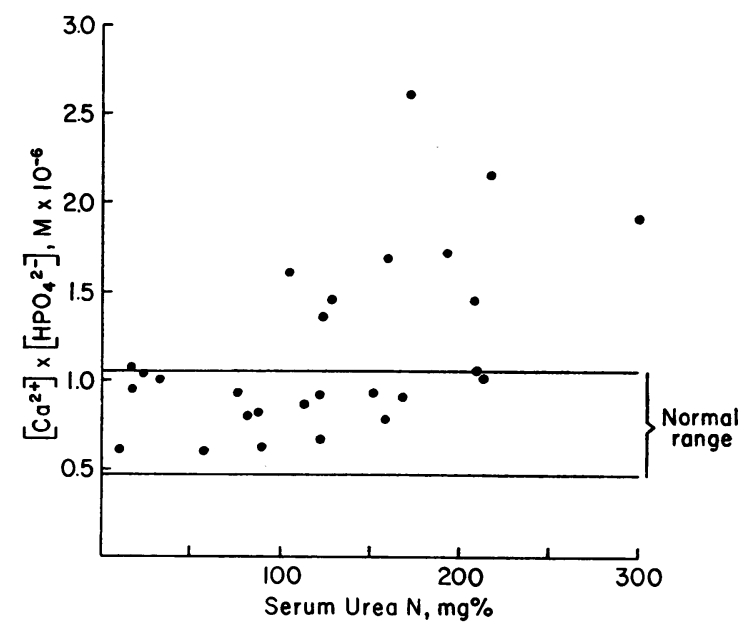

Fig. 3. The Relationship between the ion PRODUCT $\left[\mathrm{CA}^{2+}\right]\left[\mathrm{HPO}_{4}{ }^{2-}\right]$ AND UREA RETENTION IN SUBJECTS WITH PRIMARY RENAL DISEASE. The scale is linear. 
IONIZATION OF PLASMA CALCIUM AND PHOSPHATE

TABLE VI

The effect of vitamin $D$ intoxication on four measures of the state

\begin{tabular}{|c|c|c|c|c|c|c|}
\hline Subject & Sample & {$[\mathrm{Ca}]$} & $\begin{array}{c}\text { Ratio } \\
{\left[\mathrm{Ca}^{2+}\right] /[\mathrm{Ca}]}\end{array}$ & $K_{\text {caProt }}$ & {$\left[\mathrm{Ca}^{2+}\right]\left[\mathrm{HPO}_{4}{ }^{2-}\right]$} & Complexed Ca \\
\hline & & mmoles /L & & $M$ & $M \times 10^{-6}$ & $\%$ of total \\
\hline Wal & $\begin{array}{c}\text { On low dosage } \\
\text { Toxic }\end{array}$ & $\begin{array}{l}2.20 \\
3.05\end{array}$ & $\begin{array}{l}0.35 \\
0.46\end{array}$ & $\begin{array}{l}0.0050 \\
0.0060\end{array}$ & $\begin{array}{l}0.43 \\
0.53\end{array}$ & $\begin{array}{r}11 \\
4\end{array}$ \\
\hline Har & $\begin{array}{l}\text { Untreated } \\
\text { Toxic }\end{array}$ & $\begin{array}{l}1.48 \\
3.24\end{array}$ & $\begin{array}{l}0.44 \\
0.44\end{array}$ & $\begin{array}{l}0.0113 \\
0.0051\end{array}$ & $\begin{array}{l}0.79 \\
1.02\end{array}$ & $\begin{array}{l}6 \\
4\end{array}$ \\
\hline
\end{tabular}

4. Role of hyperparathyroidism. In patients with parathyroid tumors the product $\left[\mathrm{Ca}^{2+}\right]$ $\left[\mathrm{HPO}_{4}{ }^{2-}\right]$ tended to be reduced and was below normal in 36 per cent. This finding is in contrast to the other hypercalcemic subjects and indicates that, in hyperparathyroidism, $\left[\mathrm{HPO}_{4}{ }^{2-}\right]$ may fall more than $\left[\mathrm{Ca}^{2+}\right]$ rises. In secondary hyperplasia, however, the opposite occurred. The highest values for the product were seen in these three cases, as is shown in Figure 2.

This finding was further investigated by repeated samples in Subject Bie. This individual showed progressive renal failure of 2 months' duration, apparently owing to hypertension and hyperphosphatemia without hypocalcemia (see Tables II and IV). In the hope of improving renal function, a parathyroidectomy was performed. Three extremely large hyperplastic glands and part of a fourth were removed. Before surgery and again 1 week afterward, hemodialysis was performed. The results of repeated measure-

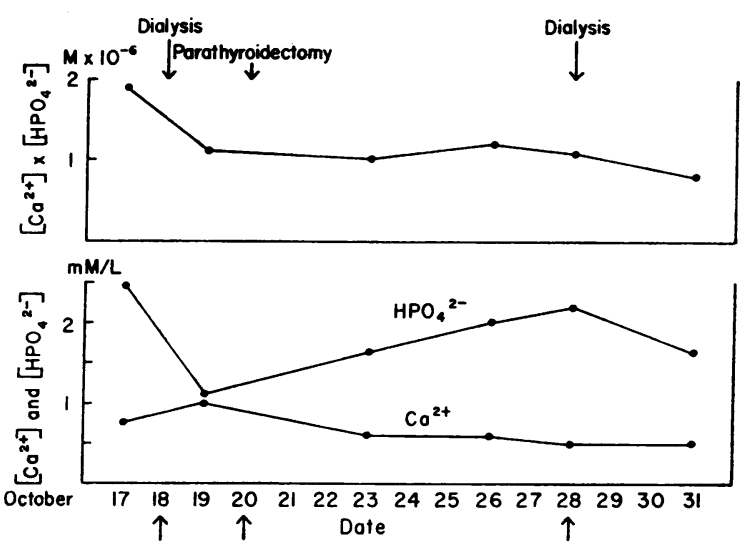

Fig. 4. Serial observations in a patient with ARTERIOLAR NEPHROSCLEROSIS AND SECONDARY HYPERPARATHYROIDISM WHO WAS SUBJECTED TO HEMODIALYSIS AND SUBTOTAL PARATHYROIDECTOMY. ments of $\left[\mathrm{Ca}^{2+}\right],\left[\mathrm{HPO}_{4}{ }^{2-}\right]$, and their product are shown in Figure 4. Despite normocalcemia, some depression of $\left[\mathrm{Ca}^{2+}\right]$ was evident in the first sample, owing to increased complexed calcium. $\left[\mathrm{HPO}_{4}{ }^{2-}\right]$ was markedly elevated, and therefore the product was also elevated. Hemodialysis raised $\left[\mathrm{Ca}^{2+}\right]$ to normal, in association with a fall in complexed calcium, but lowered $\left[\mathrm{HPO}_{4}{ }^{2-}\right]$ considerably more, so that the product fell almost to normal. After parathyroidectomy, plasma calcium, which had been stable for several weeks, fell progressively. The ion product, however, remained constant because of a reciprocal rise in $\left[\mathrm{HPO}_{4}{ }^{2-}\right]$. Total phosphate rose much more rapidly in this interval than in the preceding weeks. A second hemodialysis again lowered the ion product. Parathyroidectomy in three patients with parathyroid adenomas had no effect on this product, as shown in Table $\mathrm{V}$.

These results suggest that parathyroid hormone has little or no effect on this product except by way of its phosphaturic action, which tends to decrease it. In the absence of this mechanism, the product is held at a relatively constant value, i.e., $\left[\mathrm{HPO}_{4}{ }^{2-}\right]$ varies reciprocally with $\left[\mathrm{Ca}^{2+}\right]$ in any given subject. The product about which these reciprocal adjustments occur may be greatly increased by uremia. In secondary hyperparathyroidism the degree and duration of nitrogen retention may be marked, so that the product may be unusually high. All three of the patients with parathyroid hyperplasia had severe uremia. Presumably, if hyperplasia developed in a patient with mild uremia, little or no elevation of the product might be seen. This is borne out by the findings in the mildly azotemic subjects with parathyroid tumors, in whom the products were normal or decreased (Figure 2). 
TABLE VII

Apparent dissociation constant of calcium proteinate, $K_{\text {CaProt }}$, in various conditions

\begin{tabular}{lccc}
\hline \hline & $\begin{array}{c}\text { No. of } \\
\text { samples }\end{array}$ & Mean & $\begin{array}{c}\text { Standard } \\
\text { deviation }\end{array}$ \\
\hline & & $M$ & $M$ \\
Normal & 24 & $0.0086 \pm 0.0016$ \\
Renal disease & & & \\
$\quad$ Venous pH $<7.30$ & 15 & $\mathbf{0 . 0 1 0 1} \pm \mathbf{0 . 0 0 4 0}$ \\
Venous pH $>7.30$ & 15 & $\mathbf{0 . 0 0 9 6} \pm \mathbf{0 . 0 0 1 7}$ \\
Hypercalcemia of malignancy & 17 & $\mathbf{0 . 0 0 8 6} \pm \mathbf{0 . 0 0 2 9}$ \\
Primary hyperparathyroidism & 16 & $\mathbf{0 . 0 0 8 4} \pm \mathbf{0 . 0 0 2 1}$ \\
Secondary hyperparathyroidism & 3 & $\mathbf{0 . 0 0 8 9}$
\end{tabular}

\section{Calcium-binding ability of plasma protein}

In order to obtain a measure of the affinity of the plasma proteins for calcium, one procedure is to isolate the individual proteins and perform equilibrium dialysis with calcium solutions (11). A simpler technique estimates the effective dissociation constant of calcium proteinate in plasma, using ultrafiltration data and considering all of the plasma proteins together (12). In such calculations the role of complexed calcium is uncertain. Although chelating anions such as citrate form complexes with calcium which are apparently not bound to protein $(13,14)$, simple multivalent anions like phosphate and sulfate form ion-pair complexes with calcium which are bound to protein as much as are free calcium ions (14). A considerable proportion of the complexed calcium of plasma is unidentified (8), particularly in uremia, so that it is uncertain how much of the calcium bound to protein is also bound to anions. In calculating the dissociation constant, $K_{\text {CaProt }}$, it is therefore not clear whether one should employ the free calcium ion concentration or all of the ultrafiltrable calcium. On the unproven assumption that most of the anions that complex calcium do not alter its protein binding, we have employed the ultrafiltrable calcium. The conclusions are not altered by employing the calcium ion concentration.

$K_{\text {CaProt }}$ is calculated as follows:

$$
\begin{gathered}
K_{\mathrm{Ca} \text { Prot }}=\frac{[\mathrm{Ca}]_{\mathrm{UF}} \times([\text { Prot }]-[\mathrm{CaProt}])}{[\mathrm{CaProt}]} \\
{[\mathrm{CaProt}]=[\mathrm{Ca}]_{\mathrm{P}}-[\mathrm{Ca}]_{\mathrm{UF}}}
\end{gathered}
$$

where $[\mathrm{Ca}]_{P}$ and $[\mathrm{Ca}]_{\boldsymbol{~} F}$ represent plasma and ultrafiltrate concentrations in moles per liter, and
[Prot] represents protein equivalents in moles per liter calculated as 1.22 times total protein concentration in grams per $100 \mathrm{ml}$ (15).

The results are summarized in Table VII.

In the 24 normal subjects, $K_{\text {CaProt }}$ calculated in this manner is $0.0086 \mathrm{M} \pm 0.0016 \mathrm{M}$ (SD).

1. Role of acidosis. In 15 samples from uremic subjects with venous $\mathrm{pH}<7.30, K_{\text {CaProt }}$ was $0.0101 \mathrm{M} \pm 0.0040 \mathrm{M}$. Although this mean is somewhat higher than the normal mean, the difference is not statistically significant. However, the magnitude of the difference corresponds closely to that found in rabbit serum by Peterson, Feigen and Crismon (15). In Subject Wil, with hypercalcemia of malignancy, administration of $\mathrm{NH}_{4} \mathrm{Cl}$ sufficient to lower plasma $\mathrm{pH}$ from 7.60 to 7.25 was associated with a rise in $K_{\mathrm{CaProt}}$ from $0.0079 \mathrm{M}$ to $0.0121 \mathrm{M}$.

2. Role of renal failure. In nonacidotic subjects with renal disease, $K_{\text {CaProt }}$ was $0.0096 \mathrm{M}$ $\pm 0.0017 \mathrm{M}$, which is not significantly different from the normal subjects. There was a suggestive correlation between $K_{\text {CaProt }}$ and the serum urea nitrogen, the highest values of $K_{\mathrm{CaProt}}$ being seen in the most severe uremics. Of five subjects with serum urea nitrogen values above $100 \mathrm{mg}$ per $100 \mathrm{ml}$, three had $K_{\text {CaProt }}$ values $(0.0130 \mathrm{M}$, $0.0113 \mathrm{M}$, and $0.0115 \mathrm{M}$ ) above the normal range. Hence renal failure itself may diminish the ability of plasma proteins to bind calcium, either by altering the relative proportions of individual proteins or by a qualitative change in the proteins themselves.

3. Role of hypercalcemia. In the 17 samples from patients with hypercalcemia of malignancy, $K_{\text {CaProt }}$ was $0.0086 \mathrm{M} \pm 0.0029 \mathrm{M}$, or almost the same as in normal subjects. $K_{\text {CaProt }}$ in the two subjects with vitamin $\mathrm{D}$ intoxication was low, $0.0051 \mathrm{M}$ and $0.0060 \mathrm{M}$, respectively. An earlier sample in one of these two subjects with hypoparathyroidism, obtained before any therapy, yielded a value of $0.0113 \mathrm{M}$.

4. Role of hyperparathyroidism. $K_{\mathrm{CaProt}}$ in plasma from patients with primary hyperparathyroidism was $0.0084 \mathrm{M} \pm 0.0021 \mathrm{M}$, which is again almost the same as in normal subjects. In the three patients with secondary hyperparathyroidism, $K_{\text {CaProt }}$ averaged 0.0089 M. Parathyroidectomy had no effect on the product in three patients with tumors; in Bie, the preoperative and 
postoperative samples yielded essentially the same $K_{\text {CaProt }}($ Table $\mathrm{V})$. These observations indicate that parathyroid hormone does not appreciably alter the ability of plasma proteins to bind calcium.

\section{Complexed calcium}

The difference between ultrafiltrable calcium and free ionic calcium represents diffusible calcium complexes. Calcium citrate and secondary calcium phosphate account for some of this fraction (8), but the remainder is unidentified. The measurement of this fraction entails a rather large error, since it is obtained as the difference between two values which are usually quite close together.

The results are summarized in Table VIII. In the 24 normal subjects, the calculated amount of complexed calcium varied from -0.01 to 0.43 mmole per L (average, 0.18 ), or 7 per cent of the total plasma calcium. Only one value was greater than 0.33 mmole per $\mathrm{L}$, or 13 per cent of the total.

1. Role of acidosis. At low $\mathrm{pH}$ values, hydrogen ions displace metal ions from ligand anions, and the extent of complexing of calcium might therefore decrease in acidosis. Fanconi and Rose (16) have presented evidence that hyperventilation alkalosis increases complexed calcium; these authors pointed out that, under these circumstances, accumulation of organic anions in plasma may account for the effects observed. In acidotic subjects with renal failure, complexed calcium was often increased, but not out of proportion to the effect of uremia itself, discussed below.

2. Role of renal failure. Morison, McLean and Jackson (17), using the frog heart method, reported high values for complexed calcium in two subjects with the nephrotic syndrome. The presence or absence of azotemia in these two subjects was not stated. They concluded that nephrotic plasma may contain a factor toxic to the frog heart, invalidating these results. Fanconi and Rose (16), using Raaflaub's method (6), found an increase in complexed calcium in eight of ten patients with renal failure, including three with primary hyperparathyroidism, but not in the nephrotic syndrome uncomplicated by uremia. The upper limit of complexed calcium in their normal subjects was 0.15 mmole per $L$. The highest value seen in renal failure was 0.48 mmole per $\mathrm{L}$ in a subject with a parathyroid adenoma.
TABLE VIII

\begin{tabular}{|c|c|c|c|}
\hline & $\begin{array}{l}\text { No. of } \\
\text { samples }\end{array}$ & \multicolumn{2}{|c|}{ Mean and range } \\
\hline & & mmoles $/ L$ & $\%$ of total \\
\hline & 24 & $\begin{array}{c}0.18 \\
-0.01-0.43\end{array}$ & $\begin{array}{c}7 \\
-1-18\end{array}$ \\
\hline \multicolumn{4}{|l|}{ Renal disease } \\
\hline Venous $\mathrm{pH}<7.30$ & 15 & $\begin{array}{l}0.32 \\
0.00-0.73\end{array}$ & $\stackrel{17}{0-45}$ \\
\hline Venous $\mathrm{pH}>7.30$ & 15 & $\begin{array}{l}0.23 \\
0.00-0.55\end{array}$ & $\begin{array}{l}10 \\
0-24\end{array}$ \\
\hline Hypercalcemia of malignancy & 16 & $\begin{array}{l}0.28 \\
0.17-0.59\end{array}$ & $\stackrel{9}{1-20}$ \\
\hline Primary hyperparathyroidism & 15 & $\begin{array}{c}0.27 \\
-0.04-0.58\end{array}$ & $\begin{array}{c}9 \\
-1-24\end{array}$ \\
\hline Secondary hyperparathyroidism & 3 & $\begin{array}{l}0.33 \\
0.11-0.54\end{array}$ & $\begin{array}{l}14 \\
5-21\end{array}$ \\
\hline
\end{tabular}

In the present series, complexed calcium expressed as a fraction of total plasma calcium was above 13 per cent in more than half of patients with serum urea nitrogen values over $100 \mathrm{mg}$ per $100 \mathrm{ml}$, the highest fraction being 45 per cent (Fri). This latter value was confirmed by a second sample in the same subject, which contained only slightly less complexed calcium. In the other subjects with renal disease, complexed calcium was within normal limits. Higher values were seen in those hypercalcemic subjects who were also azotemic. Hemodialysis resulted in a reduction of complexed calcium from 21 per cent of the total calcium to 10 per cent in Bie.

3. Role of hypercalcemia. The subjects with hypercalcemia of malignancy, considered as a group, show significantly more complexed calcium than do normal subjects. However, most of them were mildly to moderately azotemic, so that this observation is probably attributable to renal failure rather than to any specific effect of malignant disease or hypercalcemia per se. Only two of them exhibited complexed calcium values above the normal range when expressed as per cent of total plasma calcium. In the hypoparathyroid subjects the rise of plasma calcium from a hypoparathyroid level to a toxic level, occasioned by vitamin $D$, was not associated with an increase in complexed calcium despite the appearance of mild azotemia (Table VI).

4. Role of hyperparathyroidism. Plasma citrate is commonly increased in hyperparathyroidism (18-21), and therefore an increase in complexed calcium might be expected. In the subjects with 
primary hyperparathyroidism, citrate levels above the upper limit of the normal subjects $(0.15$ mmole per L) were seen in half. Nevertheless, complexed calcium was not increased, either in concentration or as a fraction of the total, except in Subject Bar. The contribution of the calcium citrate complex to the complexed calcium in these subjects is considered below. Two of the three patients with secondary hyperparathyroidism showed high complexed calcium (without hypercitremia) but not more than would be consistent with their severe uremia. Parathyroidectomy produced significant decreases in the percentage of plasma calcium complexed in two of four subjects (Table V). In Subject Bar, a transient rise occurred in a sample obtained a few days postoperatively; a sample several weeks later contained less than the preoperative specimen of complexed calcium.

Vitamin D intoxication did not increase the percentage of plasma calcium complexed (Table VI). In a large series of cases, Anning, Dawson, Dolby and Ingram (22) found an increase in complexed calcium in most.

\section{Other observations}

The data in Tables III and IV are also relevant to the effect of these various conditions on the state of phosphate, citrate, and magnesium in plasma.

1. Phosphate. The distribution of phosphate between $\mathrm{H}_{2} \mathrm{PO}_{4}{ }^{-}$and $\mathrm{HPO}_{4}{ }^{2-}$ ions is dictated by $\mathrm{pH}$. Protein binding of phosphate, expressed as percentage of total plasma phosphate, was not altered by renal disease, as demonstrated in a previous paper (23). Hypercalcemia has been found by other workers to decrease the ultrafiltrability of plasma phosphate $(24,25)$. In 5 of 17 samples from patients with hypercalcemia of malignancy, and in 2 of 15 samples from patients with parathyroid tumors, the percentage of plasma phosphate found to be nonultrafiltrable was above the upper limit of normal (25 per cent). No increase was seen in the two subjects with vitamin D intoxication. The amount of the complex $\mathrm{CaHPO}_{4}$ parallels the product $\left[\mathrm{Ca}^{2+}\right]\left[\mathrm{HPO}_{4}{ }^{2-}\right]$ discussed above, since the quotient of these two quantities is a constant. The amount of the complex $\mathrm{NaHPO}_{4}^{-}$parallels the total phosphate concentration. The complex $\mathrm{MgHPO}_{4}^{-}$exhibited large variations, particularly in the uremic subjects, in whom it was often much increased.

2. Citrate. The incidence of hypercitremia in the hyperparathyroid samples has been mentioned. In the two patients with hypoparathyroidism ( $\mathrm{Ta}$ ble III), citrate rose with the development of vitamin $\mathrm{D}$ intoxication. In the patients with hypercalcemia of malignancy, half of the samples contained elevated amounts of citrate, in accord with previous evidence (26). In each of these three groups of patients, increased values for free citrate ion concentration were frequently seen; however, total citrate was above normal without a rise in the calculated value for free citrate in a few instances. The calculated amount of the complex $\mathrm{CaCit}^{-}$was always considerably smaller than was the total amount of complexed calcium. Thus, hypercitremia appears to be a nonspecific response to hypercalcemia, and is usually not explicable simply as an increase in the concentration of the calcium citrate complex.

In renal disease (Table IV), one-sixth of the samples exhibited modest elevations of citrate concentration, and one-sixth contained less citrate than normal. Hypercitremia was not seen in the three patients with secondary hyperparathyroidism.

3. Magnesium. Total and free ionic magnesium concentrations were variable in renal failure. Elevated total magnesium was more frequent ( 50 per cent) than was elevated ionic magnesium (34 per cent). Although low total magnesium was seen in only 12 per cent, low ionic magnesium was seen in 20 per cent (Table IV). As these results suggest, complexed magnesium was frequently increased (55 per cent). Neither $\mathrm{MgHPO}_{4}$ nor $\mathrm{MgCit}^{-}$accounted for this increase in most cases. Percentage protein binding of magnesium was usually normal, but was reduced in 23 per cent. No separate effect of acidosis could be discerned.

In the hypercalcemia of malignancy (Table III), total magnesium was usually reduced unless renal failure supervened. Protein binding of magnesium was normal in all. Complexed magnesium was increased in four patients, of whom three were azotemic. Vitamin D intoxication had no clear effect on magnesium.

In primary hyperparathyroidism (Table III), total and ionic magnesium were variable, being increased in some and decreased in others. Com- 
plexed magnesium was usually normal, as was percentage protein binding. Parathyroidectomy had no definite effect on these measures. No consistent effect of parathyroid activity on magnesium metabolism has been revealed by other studies $(27-32)$.

\section{DISCUSSION}

These observations are pertinent to the state of plasma calcium in patients who exhibit disturbances in protein, phosphate, or hydrogen ion concentration or diminished renal function. They also lead to certain inferences concerning the disturbances of calcium metabolism seen in these conditions.

\section{Calcium ion concentration}

1. In hyperparathyroidism. When percentage protein binding of calcium is normal, calcium ion concentration must be directly proportional to plasma calcium, unless complexed calcium is abnormally high. In primary hyperparathyroidism, percentage protein binding is normal, and complexed calcium is also normal. Consequently, percentage ionization of plasma calcium is normal; however, it does not follow that the absolute value of calcium ion concentration is always above normal limits.

Lloyd and Rose (33) reported that elevated calcium ion concentration is almost invariable in primary hyperparathyroidism even when total plasma calcium is normal. In our series, total calcium is above normal in 16 of 17 samples but $\left[\mathrm{Ca}^{2+}\right]$ is above normal in only 7. This discrepancy is more apparent than real. The control series of Lloyd and Rose is small and uniform, the percentage ionization of plasma calcium in 7 subjects varying from 65 to 69 per cent. In their 16 subjects with hyperparathyroidism, percentage ionization is $73 \pm 5$ per cent (SD), four subjects having values of 70 per cent or less. Total plasma calcium in the normal subjects was 9.2 to $10.0 \mathrm{mg}$ per $100 \mathrm{ml}$, but exceeded $10.0 \mathrm{mg}$ in all of the patients with hyperparathyroidism. Thus, total plasma calcium distinguishes hyperparathyroid from normal subjects better than does $\left[\mathrm{Ca}^{2+}\right]$ in their study, as well as in ours. In ours, the variability of $\left[\mathrm{Ca}^{2+}\right]$ is greater than that of total calcium; in theirs, variability of the control series is low. Apart from these differences in variabil- ity, the two studies, as well as three other recent reports (34-36), are substantially in agreement in showing little or no difference in percentage ionization of plasma calcium in primary hyperparathyroidism as compared with normal.

2. In other forms of hypercalcemia. Patients with hypercalcemia secondary to malignancy and those with vitamin $\mathrm{D}$ intoxication also exhibited a normal percentage ionization of plasma calcium (Figure 1), in confirmation of earlier studies (22, $35) .\left[\mathrm{Ca}^{2+}\right]$ was above normal in only 12 of these 19 samples, although total calcium was elevated in all. Again, this is a reflection of the greater variability in $\left[\mathrm{Ca}^{2+}\right]$ than is total calcium in the normal series. All of these subjects had symptoms of hypercalcemia, in contrast to the patients with hyperparathyroidism, many of whom did not.

3. In renal failure. The usual relationship between $\left[\mathrm{Ca}^{2+}\right]$ and total calcium can evidently change in renal failure in two ways : first, a diminished ability of the plasma proteins to bind calcium may occur, independent of any minor effect of acidosis; second, complexed calcium may rise considerably in severe uremia. The net effect of these two opposing alterations on the percentage ionization of plasma calcium is unpredictable, and abnormally high as well as abnormally low values are seen (Figure 1). The determination of $\left[\mathrm{Ca}^{2+}\right]$ may be of some value, therefore, in the management of severe renal failure, in which the total plasma calcium ceases to be a good index of the effective calcium concentration.

\section{$[C a][P]$ ion products}

Neuman and Neuman (37) assert that the product $\left[\mathrm{Ca}^{2+}\right]\left[\mathrm{HPO}_{4}{ }^{2-}\right]$ varies with parathyroid activity, being increased in hyperparathyroidism. ${ }^{3}$ Rasmussen (38) has suggested that it is unaltered. The results of the present experiments show that the product $\left[\mathrm{Ca}^{2+}\right]\left[\mathrm{HPO}_{4}{ }^{2-}\right]$ is decreased or unchanged in primary hyperparathyroidism. A single value in untreated hypopara-

3 These authors have also emphasized the importance of employing ion activities rather than ion concentrations. Although this is an important distinction when ionic strength is a variable, nothing is gained by applying this correction to plasma, in which ionic strength is nearly constant. Furthermore, the use of activities, which are dimensionless quantities, can lead to misleading conclusions when they are compared with concentrations. 


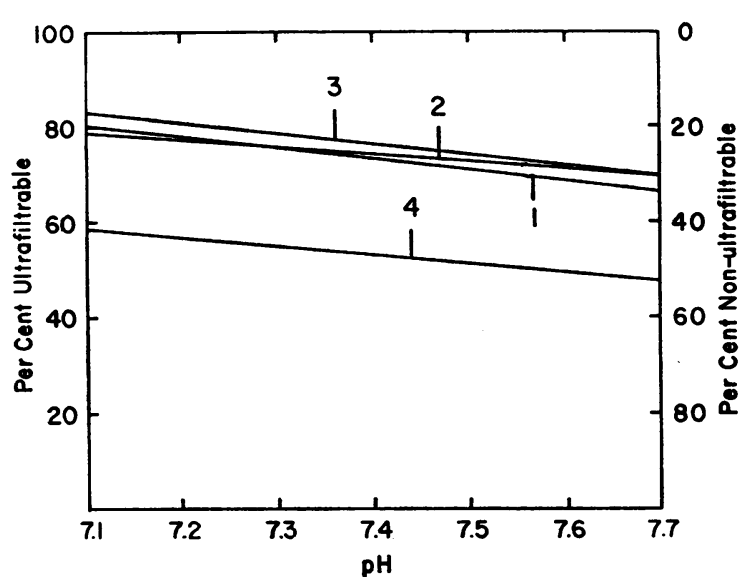

Fig. 5. THE RESUlts of FOUR PUBLISHED REPORTS OF THE EFFECT OF PLASMA $P H$ ON PROTEIN BINDING OF CALCIUM, PLOTTED ON THE SAME GRAPH. Line 1, from Hopkins, Howard and Eisenberg (56), was obtained on normal human serum at $250^{\circ} \mathrm{C}$ by anaerobic ultrafiltration. Line 2, from Toribara, Terepka and Dewey (61), represents human serum subjected to aerobic ultrafiltration at $37^{\circ} \mathrm{C}$. Line 3 , from Peterson, Feigen and Crismon (15), represents normal rabbit serum subjected to anaerobic ultrafiltration at $20^{\circ}$ to $25^{\circ} \mathrm{C}$. Line 4 , from Loken and co-workers (54), was obtained by ultracentrifugation of normal human serum at $37^{\circ} \mathrm{C}$.

thyroidism was also normal. Although this product varies twofold between different normal individuals, it appears to be more constant in a single subject, as indicated by the values before and after parathyroidectomy and by repeated determinations in some subjects.

The possibility cannot be entirely excluded that parathyroid hormone acting on bone, in the absence of a phosphaturic response, can increase the product. The two subjects with osteitis fibrosa (Rit and Sla) had the highest $\left[\mathrm{Ca}^{2+}\right]$ values and also the highest (although normal) products.

There is clearly a relationship between $\left[\mathrm{Ca}^{2+}\right]$ $\left[\mathrm{HPO}_{4}{ }^{2-}\right]$ and impairment of renal function. The most reasonable hypothesis from the data is that inhibitors of calcification accumulate in the plasma during the development of uremia and lead to the stabilization of this product at a higher value. This is consistent with the studies of Yendt and co-workers (5), mentioned above. Since hemodialysis lowered the product, one may infer that the inhibitors of calcification are dialyzable, as other work has shown (39). Until the determination of the ion product can be correlated with a measure of the mineralizing propensity of plasma, this interpretation remains conjectural. Nevertheless, the dependence of this product on renal function and its independence of parathyroid activity produces some support for the early suggestion (40) that plasma calcium falls in renal failure because phosphate rises. If phosphate accumulates more rapidly than inhibitors of calcification, then a fall in $\left[\mathrm{Ca}^{2+}\right]$ owing to mineral deposition might occur.

Is the product of total plasma calcium times total plasma phosphate a reliable index of $\left[\mathrm{Ca}^{2+}\right]$ $\left[\mathrm{HPO}_{4}{ }^{2-}\right]$ ? In molar units, the latter product is 0.2 to 0.3 times the former product in normal subjects: In the patients, this relationship was usually maintained, but a few samples in each group showed even lower values for $\left[\mathrm{Ca}^{2+}\right]\left[\mathrm{HPO}_{4}{ }^{2-}\right]$ relative to the other product. In general, however, the correlation between these two products was high.

The product $\left[\mathrm{Ca}^{2+}\right]^{3}\left[\mathrm{PO}_{4}{ }^{3-}\right]^{2}$ was also calculated in these samples. The variability in the results was very large. This increase in variability is not due to the estimation of $\left[\mathrm{PO}_{4}{ }^{3-}\right]$, which is simply a function of $\left[\mathrm{HPO}_{4}{ }^{2-}\right]$ and $\mathrm{pH}$. The variability in the product of $\left[\mathrm{Ca}^{2+}\right]\left[\mathrm{PO}_{4}{ }^{3-}\right]$ is therefore no greater than that of $\left[\mathrm{Ca}^{2+}\right]\left[\mathrm{HPO}_{4}{ }^{2-}\right]$. However, the product $\left[\mathrm{Ca}^{2+}\right]^{3}\left[\mathrm{PO}_{4}{ }^{3-}\right]^{2}$ is much more variable. These observations do not support the view (41) that this latter product is a better index of mineralizing propensity than is the product $\left[\mathrm{Ca}^{2+}\right]\left[\mathrm{HPO}_{4}{ }^{2-}\right]$. However, the actual effective product remains unknown.

\section{Protein binding of calcium}

1. Role of plasma $p H$. Although great emphasis has been laid on the effect of plasma $\mathrm{pH}$ on protein binding of calcium, it is doubtful whether the magnitude of this effect warrants such emphasis. In Figure 5 are summarized the results of four studies of this effect, recalculated and plotted so as to afford comparison. A change in $\mathrm{pH}$ of 0.3 unit, which would represent severe acidosis or alkalosis, is associated with a change in ultrafiltrable calcium which amounts to approximately 6 per cent of the total plasma calcium.

From the technical point of view, control of $\mathrm{pH}$ to within 0.1 unit or less during ultrafiltration is therefore unnecessary. Exposure of plasma to air will of course introduce much larger changes in 
$\mathrm{pH}$ and should be avoided. However, the use of a gas mixture having the same composition as the subject's alveolar air, as recommended by Rose (42), seems unnecessary. The calculated venous $\mathrm{pCO}_{2}$ in our severely acidotic subjects (venous $\mathrm{pH}<7.30$ ) averages $30 \mathrm{~mm} \mathrm{Hg}$, and the lowest value is $22 \mathrm{~mm} \mathrm{Hg}$. Although precise $\mathrm{pCO}_{2}$ values are not available because the $\mathrm{CO}_{2}$ content and $\mathrm{pH}$ were not determined on the same sample, these results establish that marked reductions of $\mathrm{pCO}_{2}$ did not occur, at least in the venous blood. Elevation of plasma $\mathrm{pCO}_{2}$ from 30 to $40 \mathrm{~mm} \mathrm{Hg}$, (i.e., equilibration with 5 per cent $\mathrm{CO}_{2}$ at $37^{\circ} \mathrm{C}$ ) can be calculated to lower plasma $\mathrm{pH}$ approximately 0.1 unit, which does not affect protein binding significantly, as the figure shows. Furthermore, it is doubtful whether the plasma in the cellophane sac reaches gaseous equilibrium with the atmosphere in the ultrafiltration apparatus we employed. And finally, any effect of metabolic acidosis on protein binding would be increased rather than decreased by using a higher $\mathrm{pCO}_{2}$. The use of venous rather than arterial plasma for determination of protein binding of calcium is justified by the same considerations. Since stasis was avoided, there is no reason to suppose that unusually large arteriovenous differences of $\mathrm{pH}$ or $\mathrm{pCO}_{2}$ occurred.

The physiological significance of alterations in protein binding of calcium induced by $\mathrm{pH}$ is also questionable. Fanconi and Rose (16) found that hyperventilation to extremely low $\mathrm{pCO}_{2}$ values ( 8 to $20 \mathrm{~mm} \mathrm{Hg}$ ) was associated with reductions in plasma $\left[\mathrm{Ca}^{2+}\right]$ averaging 20 per cent, some of which were due to rises in complexed calcium.
Much smaller reductions in $\mathrm{pCO}_{2}$ suffice to cause tetany (43), but larger reductions in plasma calcium without $\mathrm{pH}$ change are required to produce tetany as, for example, in hypoparathyroidism. In acidosis, as the results reported here indicate, plasma $\mathrm{pH}$ is not a major determinant of percentage protein binding or percentage ionization of plasma calcium. It has been shown that the hydrogen (or hydroxyl) ion is directly concerned with neuromuscular irritability (44), even though it does not affect the inotropic response of the heart to calcium ions (4). Thus, the role of plasma $\mathrm{pH}$ in producing tetany or protecting against tetany is evidently a direct one, and only a minor role can be attributed to any effect mediated by altered protein binding of calcium.

2. Role of parathyroid hormone. McLean, Barnes and Hastings (45) showed that neither parathyroid extract administration nor parathyroidectomy had an effect on $K_{\text {CaProt }}$ in cats. In Table IX, the results of studies of protein binding of calcium in patients with primary hyperparathyroidism are summarized, including studies employing ultrafiltration and ultracentrifugation. In only one report (33) has a significant difference between normal and primary hyperparathyroid subjects been shown. In this report the normal series included only seven subjects, and the variability in the normal series was small. Nevertheless, there was some overlap between patients and controls. As a result of the mass-law relationship, a slight decrease in percentage protein binding of calcium results from hypercalcemia itself. The slight difference in the mean values for

TABLE IX

Percentage protein binding of calcium in patients with primary hyperparathyroidism, according to various authors *

\begin{tabular}{|c|c|c|c|c|c|c|}
\hline \multirow[b]{2}{*}{ Reference } & \multicolumn{3}{|c|}{ Hyperparathyroid } & \multicolumn{3}{|c|}{ Controls } \\
\hline & No. & Range & Mean & No. & Range & Mean \\
\hline & & $\%$ & $\%$ & & $\%$ & \\
\hline Snell $1930(46)$ & 1 & & 52 & ? & $40-55$ & ? \\
\hline Herbert 1933 (47) & 2 & 43,45 & 44 & None & & \\
\hline Morison et al. 1938 (17) & 2 & 41,60 & 50 & 12 & $38-57$ & 48 \\
\hline Hellstrom $1953(48)$ & 3 & $33-38$ & 34 & None & & \\
\hline Hopkins et al. 1953 (25) & 9 & $24-39$ & 32 & 10 & $25-35$ & 32 \\
\hline Thomas et al. 1958 (49) & 2 & 30,31 & 30 & 10 & $25-35$ & 32 \\
\hline Lloyd and Rose 1958 & 16 & $16-30$ & 24 & 7 & $28-32$ & 30 \\
\hline Breen and Freeman 1961 (50) & 3 & $38-45$ & 40 & 14 & $44-50$ & 46 \\
\hline Fowler et al. 1961 (35) & 5 & $29-40$ & 35 & 20 & ? & 39 \\
\hline Walser 1962 (this report) & 14 & $34-54$ & 44 & 24 & $36-56$ & 47 \\
\hline
\end{tabular}

${ }^{*}$ Percentage protein binding calculated as $100 \times\left[1-\left(\mathrm{UF}_{\mathrm{Ca}} / \mathrm{P}_{\mathrm{Ca}}\right)\right]$, without corrections for water content or Donnan factor. 
percentage protein binding in the present series ( 44 per cent in hyperparathyroidism versus 47 per cent in controls) disappears (actually is reversed) when $K_{\text {CaProt }}$ is calculated $(0.0084 \mathrm{M}$ in hyperparathyroidism versus $0.0086 \mathrm{M}$ in controls). In one subject with untreated hypoparathyroidism, $K_{\text {CaProt }}$ was in the high normal range $(0.0113 \mathrm{M})$, indicating a low normal affinity of plasma protein for calcium in the subject. Terepka, Toribara and Dewey (10) found normal percentage protein binding of calcium in hypoparathyroidism. If all available data are considered, it appears that parathyroid hormone has no effect on the ability of plasma protein to bind calcium. This is also the conclusion most recently stated by Breen and Freeman (51), although they apparently feel that their earlier report (50), cited in Table IX, confirmed the conclusions of Lloyd and Rose (33). Furthermore, three recent reports, which do not appear in Table IX because complete data for this comparison are not given, agree in indicating normal percentage protein binding or ionization of plasma calcium, or both, in patients with hyperparathyroidism $(34,36,52)$.

Although a specific abnormality of the electrophoretic distribution of protein in hyperparathyroidism was indicated by Gordan (52), no characteristic change was found by McGeown (53).

\section{Colloidal calcium phosphate}

Approximately 15 per cent of plasma phosphate is not ultrafiltrable in normal subjects (23). Since addition of excess EDTA to plasma before ultrafiltration does not alter these results (23), neither calcium nor magnesium plays a role in restricting the passage of phosphate through the cellophane membrane. It is reasonable to conclude that the nonultrafiltrable phosphate is proteinbound (subject to some uncertainty in choice of the correct Donnan factor). Similar conclusions have been reached by Loken, Havel, Gordan and Whittington (54) from ultracentrifugal analysis of plasma.

When plasma phosphate is elevated, the percentage not ultrafiltrable is unaltered $(10,23)$, unless very high values are produced experimentally $(14,55,56)$, at which point the ultrafiltrability of calcium also falls. Presumably, the precipitation of secondary calcium phosphate is responsible. Several studies of hypercalcemic plasma have indicated that the ultrafiltrability of phosphate may also fall sharply under these conditions $(24,25,49,56)$.

In one-fifth of the hypercalcemic samples examined in this study, the ultrafiltrability of phosphate was less than normal. When five of these samples were subjected to ultrafiltration after the addition of 4 mmoles per $\mathrm{L}$ of the trisodium salt of EDTA, the ultrafiltrability of phosphate became normal. This observation supports the view that precipitation of calcium phosphate is involved. It remains to be determined, however, whether precipitation occurs in vivo or is produced by the withdrawal and cooling of blood.

Although the methods employed in this study can provide useful information, they are distinctly limited as diagnostic tools in these conditions. They fail to distinguish hyperparathyroidism from vitamin $\mathrm{D}$ intoxication or from the hypercalcemia of malignancy, except in those instances of hyperparathyroidism in which $\left[\mathrm{Ca}^{2+}\right]\left[\mathrm{HPO}_{4}{ }^{2-}\right]$ is below normal. They also fail to distinguish primary hyperparathyroidism with renal failure from secondary hyperplasia. They show no correlation with the presence or absence of bone disease or nephrolithiasis.

It has been established that the physiologically effective fraction of plasma calcium is the free ionic calcium. Calcium in the form of chelate complexes, such as with citrate or EDTA, is known to be ineffective in promoting the clotting of blood, the contraction of frog cardiac muscle (57), or the deposition of bone salt. Furthermore, calcium which is electrostatically associated with multivalent ions to form ion-pair complexes is also ineffective $(58-60,62)$.

Yendt and co-workers (5) found that calcification of rachitic cartilage failed to occur in some plasma samples at ultrafiltrable calcium times phosphate products which were adequate to produce calcification in artificial solutions. This observation may be cited as additional evidence that inhibitors of calcification are present in normal plasma (39). If this be so, bioassay methods involving mineralization of collagen or cartilage cannot yield values for "biologically active" calcium. Instead, they give an empirical index of mineralizing propensity, which is the net result of three (or more) factors: 1 ) the effective calcium 
concentration, 2) the effective phosphate concentration, and 3) the amount of inhibitors present. If 1) and 2) are known, these methods provide an estimate of 3 ).

The only direct method for determining the physiologically effective calcium concentration is the frog heart technique. When applied to normal plasma ultrafiltrate, this method indicates that approximately 90 per cent of the ultrafiltrable calcium is physiologically effective $(17,22)$. The free ionic calcium concentration, as measured by the murexide method, is also about 90 per cent of the ultrafiltrable calcium in normal plasma $(8,16$, $34,35,42)$. It is reasonable to conclude that the effective calcium concentration is identical with the free ionic calcium.

\section{SUMMARY}

Plasma from patients with primary and secondary hyperparathyroidism, hypercalcemia of malignancy, vitamin $\mathrm{D}$ intoxication, and primary renal failure, with and without acidosis, has been analyzed for total, free, and complexed calcium, magnesium, phosphate, and citrate. An attempt has been made to determine the separate effects of parathyroid hormone, hypercalcemia itself, renal failure, and acidosis on four indices of the state of plasma calcium.

1. The ability of plasma protein to bind calcium, measured as $K_{\mathrm{CaProt}}$. was unaltered in primary or secondary hyperparathyroidism or in the hypercalcemia of malignancy. Acidosis had only a minor effect. Renal failure itself had no effect except in some severe uremics, in whom calcium binding was decreased. Increased protein binding of phosphate, seen in one-fifth of the hypercalcemic samples, was eliminated by adding excess EDTA.

2. Complexed calcium was increased only in severe uremia. Neither phosphate nor citrate accounted for the increase.

3. The ion product $\left[\mathrm{Ca}^{2+}\right]\left[\mathrm{HPO}_{4}{ }^{2-}\right]$ was normal or low in primary hyperparathyroidism and was unaffected by parathyroidectomy in primary or secondary hyperparathyroidism. It was increased in severe renal failure but was unaffected by hypercalcemia itself. These results support the traditional concept of reciprocal adjustments in $\mathrm{Ca}$ and $\mathrm{P}$ concentrations to keep this product constant. with the modification that inhibitors of cal- cification accumulating in uremia may greatly increase the level about which these adjustments occur.

4. In accordance with these findings, the percentage ionization of plasma calcium was normal in both primary and secondary hyperparathyroidism and also in other types of hypercalcemia. Some decrease was seen in severe uremia due to increased complexed calcium. Acidosis had only a minor effect, and the absence of tetany in acidotic uremics with hypocalcemia cannot be attributed to an increase in ionization of plasma calcium.

\section{ACKNOWLEDGMENTS}

I am greatly indebted to Dr. Robert A. Johnston, Jr., Dr. Thomas B. Connor and Mr. Edward B. Marsh, Jr., for assistance in obtaining some of these samples, and to Dr. John Eager Howard for making it possible to study several patients. Sylvia Butler, Mary Jane Ford and Roberta Kromm provided valuable technical assistance.

\section{REFERENCES}

1. Walser, M. The ionic composition of uremic plasma (abstract) . J. clin. Invest. 1959, 38, 1052.

2. Marsh, E. B., Jr., and Walser, M. Filtrable calcium complexes in the hypercalcemia of malignancy. Clin. Res. 1961, 9, 205.

3. Walser, M. Plasma $\left[\mathrm{Ca}^{2+}\right]$ and $\left[\mathrm{Ca}^{2+}\right]\left[\mathrm{HPO}_{4}{ }^{2-}\right]$ in hyperparathyroidism and in renal failure. Clin. Res. 1961, 9, 338.

4. McLean, F. C., and Hastings, A. B. A biological method for the estimation of calcium ion concentration. J. biol. Chem. 1934, 107, 337.

5. Yendt, E. R., Connor, T. B., and Howard, J. E. In vitro calcification of rachitic rat cartilage in normal and pathological human sera with some observations on the pathogenesis of renal rickets. Bull. Johns Hopk. Hosp. 1955, 96, 1.

6. Raaflaub, J. Uber ein photometrisches Verfahren zur Bestimmung des ionisierten Calciums. HoppeSeylers Z. physiol. Chem. 1951, 288, 228.

7. Walser, M. Determination of free magnesium ions in body fluids. Improved methods for free calcium ions, total calcium, and total magnesium. Analyt. Chem. 1960, 32, 711.

8. Walser, M. Ion Association. VI. Interactions between calcium, magnesium, inorganic phosphate, citrate and protein in normal human plasma. J. clin. Invest. 1961, 40, 723.

9. Annino, J. S., and Relman, A. S. The effect of eating on some of the clinically important chemical constituents of the blood. Amer. J. clin. Pathol. 1959, 31, 155.

10. Terepka, A. R., Toribara, T. Y., and Dewey, P. A. The ultrafiltrable calcium of human serum. II. 
Variations in disease states and under experimental conditions. J. clin. Invest. 1958, 37, 87.

11. Martin, N. H., and Perkins, D. J. The calcium binding of human serum albumin in health and disease. Biochem. J. 1953, 54, 642.

12. McLean, F. C., and Hastings, A. B. The state of calcium in the fluids of the body. I. The conditions affecting the ionization of calcium. J. biol. Chem. 1935, 108, 285.

13. Shelling, D. H., and Maslow, H. L. The effect of sodium citrate, acetate, and lactate on the ultrafiltrability of serum calcium. J. biol. Chem. 1928, 78, 661 .

14. Walser, M. Ion Association. I. The effect of multivalent anions on the protein-bound and complexed calcium in serum. J. cell. comp. Physiol. 1960, 55, 245.

15. Peterson, N. A., Feigen, G. A., and Crismon, J. M. Effect of $\mathrm{pH}$ on interaction of calcium ions with serum proteins. Amer. J. Physiol. 1961, 201, 386.

16. Fanconi, A., and Rose, G. A. The ionized, complexed, and protein-bound fractions of calcium in plasma. Quart. J. Med. 1958, 27, 463.

17. Morison, R. S., McLean, R., and Jackson, E. B. Observations on the relation between ionized and total calcium in normal and abnormal sera and their ultrafiltrates. J. biol. Chem. 1937-8, 122, 439.

18. Alwall, N. Studien über die Regulation vom Citronensäuregehalt des Blutserums IV: Über die Einwirkung von Parathormon auf den Citronensäuregehalt des Blutserums, ein Beitrag zur Frage des Zusammenhangs zwischen Calcium und Citronensäure. Acta med. scand. 1944, 116, 337.

19. Sjöström, P. Der Citratgehalt im Blutserum als Diagnosticum bei Krankheiten der Leber und der Gallenwege: Eine methodologische, tierexperimentelle und klinische Studie. Acta chir. scand. 1937, 79, suppl. 49.

20. L'Heureux, M. V., and Roth, G. J. Influence of parathyroid extract on citric acid of the serum. Proc. Soc. exp. Biol. (N. Y.) 1953, 84, 7.

21. Watson, L. Citrate metabolism in hyperparathyroidism. Proc. roy. Soc. Med. 1959, 52, 349.

22. Anning, S. T., Dawson, J., Dolby, D. E., and Ingram, J. T. The toxic effects of calciferol. Quart. J. Med. 1948, 17, 203.

23. Walser, M. Protein-binding of inorganic phosphate in plasma of normal subjects and patients with renal disease. J. clin. Invest. 1960, 39, 501.

24. Grollman, A. The condition of the inorganic phosphorus of the blood with special reference to the calcium concentration. J. biol. Chem. 1927, 72, 565 .

25. Hopkins, T. R., Connor, T. B., and Howard, J. E. Ultrafiltration studies on calcium and phosphorus in pathological human serum. Bull. Johns Hopk. Hosp. 1953, 93, 249.

26. Lemon, H. M., Mueller, J. H., Looney, J. M., Chasen, W. H., and Kelman, M. Hypercitricemia in hu- man cancer; factors concerned in pathogenesis and treatment. Brit. J. Cancer 1960, 14, 376.

27. Greenberg, D. M., and Mackey, M. A. The effect of parathyroid extract on blood magnesium. J. biol. Chem. 1932, 98, 765.

28. Bulger, H. A., and Gausmann, F. Magnesium metabolism in hyperparathyroidism. J. clin. Invest. 1933, $12,1135$.

29. Agna, J. W., and Goldsmith, R. E. Primary hyperparathyroidism associated with hypomagnesemia. A report of three cases (abstract). J. clin. Endocr. 1956, 16, 973.

30. Barnes, B. A., Krane, S. M., and Cope, O. Magnesium studies in relation to hyperparathyroidism. J. clin. Endocr. 1957, 17, 1407.

31. Durlach, J., Stoliaroff, M., Gauduchon, J., Leluc, R., and Cong-Trieu, T. Studies on the relations between parathyroid glands and magnesium metabolism. Ann. Endocr. (Paris) 1960, 21, 242.

32. Scholtz, H. G. Notiz über die Wirkung des Parathyreoidea-Hormons auf den Magnesiumgehalt des Blutes. Naunyn-Schmiedeberg's Arch. exp. Path. Pharmak. 1931, 159, 233.

33. Lloyd, H. M., and Rose, G. A. Ionised, proteinbound, and complexed calcium in plasma in primary hyperparathyroidism. Lancet 1958, 2, 1258.

34. Hyde, R. D., Jones, R. V., McSwiney, R. R., and Prunty, F. T. G. Investigation of hyperparathyroidism in the absence of bone disease. Lancet 1960, 1, 250.

35. Fowler, D., Fone, D. J., and Cooke, W. T. The calcium fractions of plasma in hypercalcaemic conditions and in adult coeliac disease. Lancet 1961, 2, 284.

36. McSwiney, R. R., and Prunty, F. T. G. The diagnosis of minimal hyperparathyroidism. Determination of theoretical renal phosphorus threshold. Proc. roy. Soc. Med. 1961, 54, 639.

37. Neuman, W. F., and Neuman, M. W. The Chemical Dynamics of Bone Mineral. Chicago, Univ. of Chicago Press, 1958.

38. Rasmussen, H. Parathyroid hormone. Nature and mechanism of action. Amer. J. Med. 1961, 30(1), 112.

39. Fleish, H., and Neuman, W. F. Mechanisms of calcification: Role of collagen, polyphosphates, and phosphatase. Amer. J. Physiol. 1961, 200, 1296.

40. Albright, F., and Reifenstein, E. C., Jr. The Parathyroid Glands and Metabolic Bone Disease. Baltimore, Williams \& Wilkins, 1948.

41. MacGregor, J., and Nordin, B. E. C. Equilibration studies with human bone powder. J. biol. Chem. 1960, 235, 1215.

42. Rose, G. A. Determination of the ionised and ultrafilterable calcium of normal human plasma. Clin. chim. Acta 1957, 2, 227.

43. Grant, S. B., and Goldman, A. A study of forced respiration: Experimental production of tetany. Amer. J. Physiol. 1920, 52, 209. 
44. Kugelberg, E. Accommodation in human nerves, and its significance for the symptoms in circulatory disturbances and tetany. Acta physiol. scand., 1944, 8, suppl. 24.

45. McLean, F. C., Barnes, B. O., and Hastings, A. B. The relation of the parathyroid hormone to the state of calcium in the blood. Amer. J. Physiol. $1935,113,141$.

46. Snell, A. M. The diffusibility of the calcium in the blood serum under normal and pathologic conditions. Proc. Mayo Clin. 1930, 5, 17.

47. Herbert, F. K. The total and diffusible calcium of serum and the calcium of cerebrospinal fluid in human cases of hypocalcaemia and hypercalcaemia. Biochem. J. 1933, 27, 1978.

48. Hellstrom, J. Observations regarding the prognosis and diagnosis of hyperparathyroidism. Cleveland Clin. Quart. 1953, 20, 253.

49. Thomas, W. C., Jr., Wiswell, J. G., Connor, T. B., and Howard, J. E. Hypercalcemic crisis due to hyperparathyroidism. Amer. J. Med. 1958, 24, 229.

50. Breen, M., and Freeman, S. The use of high centrifugal force in separating plasma calcium into its protein-bound and protein-free fractions. Clin. chim. Acta 1961, 6, 181.

51. Breen, M., and Freeman, S. Plasma calcium distribution in relation to parathyroid function. Amer. J. Physiol. 1961, 200, 341.

52. Gordan, G. S. Current status of laboratory tests for hyperparathyroidism. Acta Endocr. (Kbh.) 1960, suppl. 51, 463.

53. McGeown, M. G. The value of the calcium infusion test, tests of renal tubular function and changes in the serum proteins in the diagnosis of hyperparathyroidism. Proc. roy. Soc. Med. 1961, 54, 642.

54. Loken, H. F., Havel, R. J., Gordan, G. S., and Whittington, S. L. Ultracentrifugal analysis of proteinbound and free calcium in human serum. J. biol. Chem. 1960, 235, 3654.

55. McLean, F. C., and Hinrichs, M. A. The formation and behavior of colloidal calcium phosphate in the blood. Amer. J. Physiol. 1938, 121, 580.

56. Hopkins, T., Howard, J. E., and Eisenberg, H. U1trafiltration studies on calcium and phosphorus in human serum. Bull. Johns Hopk. Hosp. 1952, $91,1$.

57. Hastings, A. B., McLean, F. C., Eichelberger, L., Hall, J. L., and Da Costa, E. The ionization of calcium, magnesium, and strontium citrates. J. biol. Chem. 1934, 107, 351.

58. Giebisch, G., Kraupp, O., Pillat, B., and Stormann, H. Die Wirkung der Sulfationen auf das Membranpotential der isoliert durchströmten Säugetiermuskulatur. Experientia (Basel) 1957, 13, 445.

59. Lovelock, J. E., and Porterfield, B. M. Blood clotting: The function of electrolytes and of calcium. Biochem. J. 1952, 50, 415.

60. Falk, G., and Landa, J. F. Prolonged response of skeletal muscle in the absence of penetrating anions. Amer. J. Physiol. 1960, 198, 289.

61. Toribara, T. Y., Terepka, A. R., and Dewey, P. A. The ultrafiltrable calcium of human serum. I. Ultrafiltration methods and normal values. J. clin. Invest. 1957, 36, 738.

62. Payne, J. W., and Walser, M. Ion Association. II. The effect of multivalent ions on the concentration of free calcium ions as measured by the frog heart method. Bull. Johns Hopk. Hosp. 1959, 105, 298. 